\title{
Faktor-faktor yang mempengaruhi tingkat fertilitas di perdesaan (Studi pada Desa Pelayangan Kecamatan Muara Tembesi Kabupaten Batanghari)
}

\author{
Lennaria Sinaga; Hardiani*; Purwaka Hari Prihanto
}

Prodi Ekonomi Pembangunan, Fakultas Ekonomi dan Bisnis, Universitas Jambi

*E-mail korespondensi:hardiani@unja.ac.id

\begin{abstract}
This study aims to analyze the factors that affect fertility in rural areas by taking the case of Pelayangan Village, Muara Tembesi District, Batanghari Regency. The study used a survey method with a sample of women of childbearing age in the study village. The analytical tool used is path analysis. The results of the analysis found that simultaneously women's education, family income and age at first marriage had a significant effect on fertility. Partially based on path analysis shows that a) The age of first marriage has a significant negative effect on fertility. The higher the age at first marriage, the lower the fertility rate; $b$ ) Women's education has a significant negative effect on fertility both directly and indirectly through the age of first marriage; $c$ ) Income does not have a significant effect on fertility either directly or indirectly through the age of first marriage.
\end{abstract}

Keywords: Education, Income, Age of First Marriage, Fertility, Path Analysis.

\begin{abstract}
Abstrak
Penelitian ini bertujuan untuk menganalisis faktor-faktor yang mempengaruhi fertilitas di perdesaan dengan mengambil kasus Desa Pelayangan Kecamatan Muara Tembesi Kabupaten Batanghari. Penelitian menggunakan metode survai dengan sampel adalah wanita pasangan usia subur di desa penelitian. Alat analisis yang digunakan adalah analisis jalur (path analysis). Hasil analisis menemukan bahwa secara simultan pendidikan wanita, pendapatan keluarga dan usia kawin pertama berpengaruh signifikan terhadap fertilitas. Secara parsial berdasarkan analisis jalur menunjukkan bahwa a) Usia kawin pertama berpengaruh signifikan negatif terhadap fertilitas. Semakin tinggi usia kawin pertama, akan menurunkan tingkat fertilitas; b) Pendidikan wanita berpengaruh signifikan negatif terhadap fertilitas baik secara langsung maupun tidak langsung melalui usia kawin pertama; c) Pendapatan tidak berpengaruh signifikan terhadap fertilitas baik secara langsung maupun secara tidak langsung melalui usia kawin pertama.
\end{abstract}

Kata Kunci : Pendidikan, Pendapatan, Usia Kawin Pertama, Fertilitas, Path Analysis.

\section{PENDAHULUAN}

Masalah kependudukan di Indonesia adalah jumlah penduduk yang besar dan laju pertumbuhan yang tinggi. Jumlah penduduk semakin meningkat dari tahun ke tahun baik di dunia maupun di Indonesia. Jumlah penduduk yang besar dengan laju pertumbuhan yang tinggi akanmenghambat usaha peningkatan dan pemerataan kesejahteraan rakyat di berbagai bidang kehidupan. Jumlah penduduk mengakibatkan rendahnya taraf kehidupan penduduk serta ketidakmampuan pemerintah 
menanggulanginya. Salah satu faktor yang mempengaruhi jumlah penduduk dan laju pertumbuhan penduduk yang besar adalah fertilitas. Berdasarkan data SDKI tahun 2012 total fertility rate di Indonesia sebesar 2,6\% sedangkan TFR per provinsi tingkat fertilitas tertinggi di Kalimantan Barat yaitu sebesar 3,10\% dan yang terendah di provinsi Yogyakarta 2,10\%, dan di Provinsi Jambi sebesar 2,30\%.

Menurut Mantra dalam Rakhmatullah (2015) pengendalian fertilitas merupakan salah satu cara untuk mengendalikan jumlah penduduk. terdapat sejumlah faktor yang dapat mempengaruhi tingkat fertilitas yaitu, (1) faktor demografi yang terdiri dari : komposisi umur, status perkawinan, umur kawin pertama, fekuditas, proporsi penduduk yang bersatatus kawin, dan (2) Faktor non demografi diantaranya ekonomi penduduk, tingkat pendidikan, perbaikan status wanita, urbanisasi dan industrialisasi. Faktor-faktor tersebut dapat berpengaruh langsung ataupun tidak langsung terhadap fertilitas. Selain itu faktor sosial juga dapat mempengaruhi tingkat pendidikan ibu, statusketenagakerjaan ibu, usia kawin pertama ibu, penggunaan alat kontrasepsi dan tingkat pendapatan orang tua.

Pendapatan adalah faktor yang paling dominan dalam mempengaruhi suatu keputusan seseorang atau keluarga dalam merencanakan jumlah anak. Davis dan Blake 1956 dalam Hatmadji (2004) menyatakan bahwa faktor-faktor sosial mempengaruhi fertilitas melalui variabel antara. Salah satu variabel antara yang dikemukakan oleh Davis dan Blake adalah umur memulai hubungan kelamin. Umur memulai hubungan kelamin yang rendah mempunyai pengaruh positif terhadap kelahiran yang artinya makin rendah usia kawin pertama akan diikuti oleh kelahiran yang semakin banyak.

Berdasarkan hal tersebut, penelitian ini bertujuan untuk menganalisis faktorfaktor yang mempengaruhi fertilitas. Studi dilakukan di Desa Pelayangan yang merupakan salah satu desa di Kecamatan Muara Tembesi Kabupaten Batanghari Provinsi Jambi.

\section{TINJAUAN PUSTAKA}

\section{Konsep fertilitas dan faktor-faktor yang mempengaruhinya}

Fertilitas diartikan sebagai kemampuan seorang wanita untuk menghasilkan kelahiran hidup merupakan salah satu faktor penambah jumlah penduduk disamping migrasi masuk, tingkat kelahiran dimasa lalu mempengaruhi tingginya tingkat fertilitas masa kini. Fertilitas merupakan hasil reproduksi nyata dari seorang atau sekelompok wanita, sedangkan dalam pengertian demografi menyatakan banyaknya bayi yang lahir hidup. Besar kecilnya jumlah kelahiran dalam suatu penduduk, tergantung pada beberapa faktor misalnya, struktur umur, tingkat pendidikan, umur pada waktu kawin pertama, banyaknya perkawinan, status pekerjaan wanita, penggunaan alat kontrasepsi dan pendapatan/kekayaan Adioetomo dan Samosir (2011).

Menurut Davis dalam Bagoes Mantra (2003), faktor-faktor yang mempengaruhi tinggi rendahnya fertilitas dapat dibagi menjadi dua, yaitu faktor demografi dan faktor non-demografi. Faktor demografi diantaranya adalah struktur umur, struktur perkawinan, umur kawin pertama, paritas, disrupsi perkawinan, dan proporsi yang kawin. Sedangkan faktor non-demografi antara lain keadaan ekonomi penduduk, tingkat pendidikan, perbaikan status perempuan, urbanisasi dan industrialisasi. Davis dalam Mantra, (2003) dalam tulisannya berjudul The Social Structure of Fertility: An Analitical Framework, menyatakan bahwa faktor-faktor sosial mempengaruhi fertilitas melalui variabel antara. Menurut pengertian demografi, fertilitas lebih di kaitkan dengan banyaknya anak lahir hidup. Selain itu istilah fertilitas dapat di artikan dengan kelahiran hidup (live birth), yaitu selepasnya bayi dari rahim seorang perempuan dengan menunjukan tanda- tanda kehidupan, misalnya berteriak, bernafas, jantung berdenyut, dan sebagainya. 


\section{Tingkat pendidikan dan fertilitas}

Tingkat pendidikan erat kaitannya dengan perubahan sikap, prilaku, pandangan, dan status sosial ekonomi suatu masyarakat. Tingkat pendidikan merupakan faktor yang mempengaruhi tingkat fertilitas, dimana tingkat pendidikan merupakan salah satu pendorong tingkat kesejahteraan masyarakat dan berdampak pada pertumbuhan ekonomi yang tinggi. Jika waktu yang di tempuh wanita panjang untuk menyelesaikan pendidikannya akan menyebabkan perkawinan tertunda dan membuka pilihan antara bekerja dan membesarkan anak. Pendidikan yang lebih tinggi berarti kehidupan ekonomi yang lebih terjamin, dan ini biasanya tingkat fertilitas dalam suatu keluarga juga tergolong rendah.

Pendidikan diharapkan dapat menjadi sarana yang baik dalam menerapkan kebijakan dalam pemerataan pembangunan. Semakin meratanya tingkat pendidikan di setiap daerah dan strata sosial memungkinkan masalah kesenjangan sosial dapat diatasi. Masyarakat yang miskin menjadi cerdas akan dapat maju atau berkembang jika mereka memiliki akses terhadap pendidikan (pendidikan yang baik), sama dengan akses yang dimiliki oleh masyarakat yang kaya yang cerdas pula .

Wanita yang memperoleh kesempatan pendidikan tidak hanya di daerah perkotaan saja, namun juga dialami wanita di daerah pedesaan. Wanita yang tingkat pendidikannya lebih tinggi umumnya umur perkawinan pertama juga tinggi dan pada akhirnya akan mempengaruhi jumlah anak yang dilahirkan yang akan lebih sedikit.

Pendidikan sebagai variabel sosial dan ekonomi akan berpengaruh secara tidak langsung terhadap fertilitas. Bagi seorang wanita semakin tinggi pendidikan yang ditempuhnya akan semakin mengurangi masa reproduksi yang akan dilaluinya dan semakin tinggi umur dalam menempuh usia kawin pertamanya. Hal ini menyebabkan akan semakin kecil kemampuan fekunditas dari seorang wanita untuk melahirkan. Sebaliknya apabila tingkat pendidikan rendah akan mendorong seorang wanita untuk memulai usia kawin pertamanya dalam usia yang masih sangat muda, hal ini pada gilirannya akan menyebabkan masa reproduksi yang dilaluinya semakin panjang dan akan semakin tinggi masa fekunditas dan fertilitas yang dapat dilaluinya.

\section{Usia kawin pertama dan fertilitas}

Menurut Davis dalam Notoatmojo (2003) usia kawin pertama adalah usia ketika seseorang memulai atau melangsungkan pernikahan (perkawinan pertama), wanita yang menikah pada usia muda mempunyai waktu yang lebih panjang berisiko untuk hamil dan angka kelahiran juga lebih tinggi. Masalah pernikahan merupakan salah satu bagian dari masalah kependudukan yang perlu diberi perhatian khusus, karena nantinya pernikahan dapat menimbulkan masalah baru dibidang kependudukan yang nantinya dapat menghambat pembangunan. Usia kawin pertama merupakan salah satu yang dapat mempengaruhi tingkat produktifitas pada Pasangan Usia Subur (PUS).

Usia kawin pertama nantinya akan memberikan sumbangan terhadap angka kelahiran. Rata-rata umur penduduk saat menikah pertama kali serta lamanya seseorang dalam status perkawinan akan mempengaruhi tinggi rendahnya fertilitas. Menjadi di usia dini menjadi perhatian penentuan kebijakan serta perencana program karena beresiko tinggi terhadap kegagalan perkawinan, kehamilan usia muda yang beresiko kematian, serta resiko tidak siap mental untuk membina perkawinan dan menjadi orang tua yang bertanggung jawab. Umur pada saat perkawinan pertama dapat mempengaruhi kesehatan reproduksi wanita. Seorang wanita cenderung akan mempunyai resiko yang semakin lebih besar ketika melahirkan, bahkan tidak jarang menimbulkan kematian pada ibu atau bayi yang dilahirkan bila umur perkawinan pertama semakin muda. 


\section{METODE PENELITIAN}

\section{Populasi}

Populasi dalam penelitian ini seluruh wanita di pasangan usia subur di desa Pelayangan kabupaten Batanghari. Jumlah populasi di desa Pelayangan kabupaten Batanghari berjumlah 228 PUS, yang terbagi atas 4 Dusun yaitu Dusun Malako Kecil terdiri dari 153 KK, Dusun Bukit Berbunga terdiri dari 133 KK, Dusun Bukit Paku terdiri dari 126 KK, dan Dusun Bukit Berkilau 114 KK.

\section{Sampel}

Penelitian ini menggunakan persen kelonggaran ketidaktelitian karena kesalahan pengambilan sampel yang masih dapat ditolerir atau diinginkan sebesar 13\%. Jumlah sample dihitung berdasarkan rumus Slovin:

$\mathrm{n}=\frac{\mathrm{N}}{1+\mathrm{N}\left(\mathrm{e}^{2}\right)}$

Dimana

$$
\begin{aligned}
& =\frac{\mathrm{N}}{1+\mathrm{N}\left(\mathrm{e}^{2}\right)} \\
& =\frac{228}{1+228\left(0,13^{2}\right)}(0,0169) \frac{228}{4,8532} \\
& =46,97 \\
& =47 \text { sampel } \\
& =\text { Jumlah Sampel } \\
& \mathrm{N}=\text { Jumlah Populasi (responden) } \\
& e^{2}=\text { Margin eror yang diperkenankan. }
\end{aligned}
$$

Dari perhitungan tersebut maka sampel yang didapat untuk penelitian ini adalah sebanyak 47 PUS. Jumlah tersebut dianggap cukup mewakili dalam penelitian dan sudah dapat dipertanggung jawabkan secara ilmiah.

Teknik pengambilan menggunakan proporsional random sampling berdasarkan jumlah populasi di tingkat dusun. Berdasarkan hal tersebut, jumlah sampel yang diambil tiap dusun adalah sebagai berikut.

\section{Tabel 1. Distribusi proporsional sampling}

\begin{tabular}{clcc}
\hline No & Dusun & Populasi & Sampling \\
\hline 1 & Dusun I & 66 PUS & $14 \mathrm{KK}$ \\
2 & Dusun II & 58 PUS & $12 \mathrm{KK}$ \\
3 & Dusun III & 54 PUS & $11 \mathrm{KK}$ \\
4 & Dusun IV & 50 PUS & $10 \mathrm{KK}$ \\
& Jumlah & 228 PUS & $47 \mathrm{KK}$ \\
\hline
\end{tabular}

Sumber : Data Di Olah Tahun 2017

\section{Alat analisis}

Untuk menganalisis pengaruh faktor tingkat pendidikan, pendapatan keluarga dan usia kawin pertama dalam mempengaruhi fertilitas digunakan analisis jalur (path analysis), dengan kerangka jalur dan persamaan regresi sebagai berikut : 


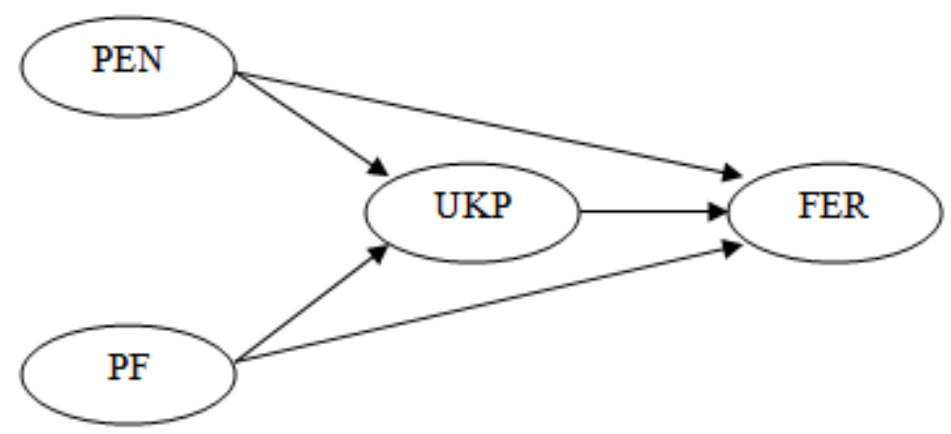

Gambar 1. Kerangka jalur penelitian

Selanjutnya kerangka jalur tersebut dirumuskan dalam model persamaan regresi sebagai berikut:

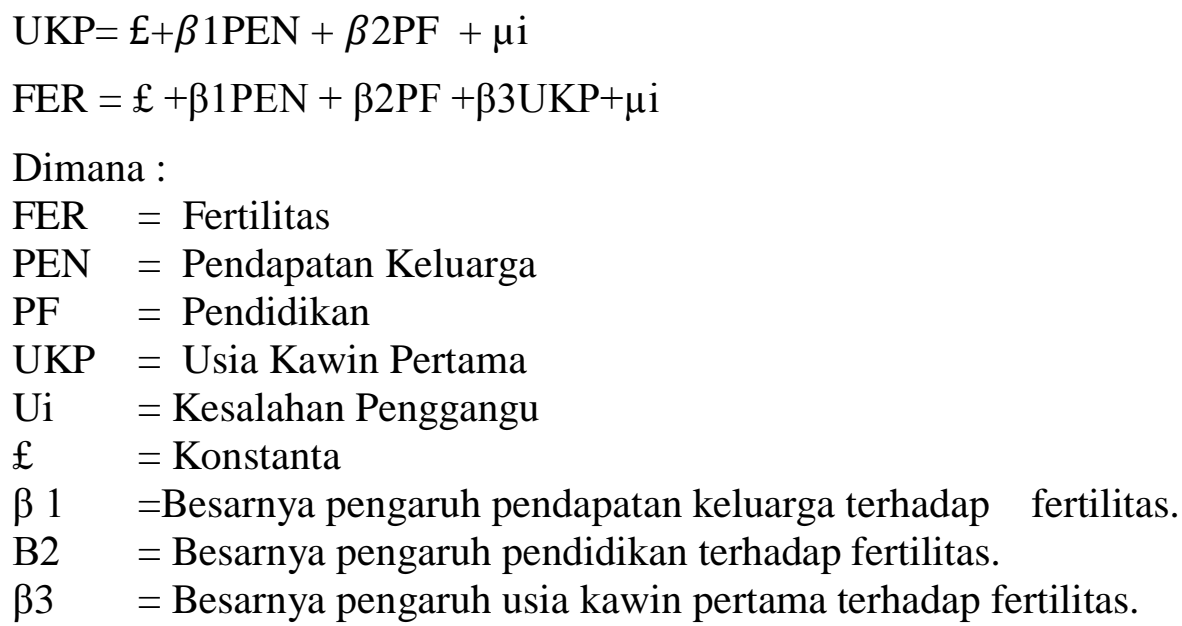

\section{HASIL DAN PEMBAHASAN}

Model pertama yaitu model yang mengestimasi pengaruh pendapatan dan pendidikan formal terhadap usia kawin pertama diberikan pada Tabel 1 berikut:

Tabel 1. Estimasi pengaruh pendapatan dan pendidikan formal terhadap usia kawin pertama di Desa Pelayangan

\begin{tabular}{cccc}
\hline Variabel & Koefisien beta & t-hitung & Signifikansi \\
\hline PEN & $-0,432$ & $-0,209$ & 0,8349 \\
PF & 1,445 & 6,222 & 0,0000 \\
\hline & F-hitung $=19,539$ & 0,0000 \\
& & R2 $=0,470$ & \\
\hline
\end{tabular}

Berdasarkan estimasi model diperoleh koefisien determinasi $\mathrm{R}^{2}$ sebesar 0,470 . Ini memberikan pengertian bahwa usia kawin pertama di desa Pelayangan di pengaruhi oleh tingkat pendidikan dan pendapatan keluarga sebesar $47,00 \%$ sedangkan, sisanya sebesar 53\% dipengaruhi oleh faktor lain di luar model.

Nilai F-hitung 19,53974 dengan signifikansi = 0,000 maka Ha diterima dan Ho ditolak. Artinya secara simultan variabel independent yaitu pendapatan, pendidikan secara bersama-sama berpengaruh signifikan terhadap usia kawin pertama di Desa Pelayangan. 
Secara parsial, pendidikan formal ibu berpengaruh secara signifikan terhadap usia kawin pertama yang dapat di buktikan dengan nilai t-hitung yang di peroleh sebesar 6,222 dengan signifikansi=0,0000. Meskipun demikian, pendapatan keluarga tidak berpengaruh signifikan terhadap usia kawin pertama (signifikansi 0,8349).

Selanjutnya model kedua yaitu model yang mengestimasi pengaruh pendidikan, pendidikan formal dan usia kawin pertama terhadap fertilitas

Tabel 2. Estimasi pengaruh pendidikan, pendidikan formal dan usia kawin pertama terhadap fertilitas di Desa Pelayangan

\begin{tabular}{llll}
\hline Variabel & Koefisien beta & t-hitung & Signifikansi \\
\hline PEN & $-0,002$ & 0,719 & 0,4758 \\
PF & $-0,307$ & $-1,939$ & 0,0590 \\
UKP & $-0,467$ & 6,090 & 0,0000 \\
\hline \multicolumn{2}{c}{ F-hitung $=35,88$} & 0,0000 \\
& \multicolumn{2}{c}{ R2 $=0,714$} \\
\hline
\end{tabular}

Berdasarkan estimasi model diperoleh koefisien determinasi $\mathrm{R}^{2}$ sebesar 0,714. Ini memberikan pengertian bahwa fertilitas di desa Pelayangan di pengaruhi oleh tingkat pendidikan, pendapatan keluarga, usia kawin pertama sebesar 71,40 sedangkan, sisanya sebesar 28,60\% dipengaruhi oleh faktor lain di luar model.

Nilai F-hitung 35,88 dengan signifikansi $=0,000$ maka Ha diterima dan Ho ditolak. Artinya secara simultan variabel independent yaitu pendapatan, pendidikan dan usia kawin pertama secara bersama-sama berpengaruh signifikan terhadap fertilitas di desa Pelayangan.

Secara parsial, pendidikan formal ibu berpengaruh secara signifikan terhadap usia kawin pertama yang dapat di buktikan dengan nilai t-hitung yang di peroleh sebesar $-1,939$ dengan signifikansi=0,0590. Usia kawin pertama juga menunjukkan pengaruh yang signifikan terhadap fertilitas dengan nilai t-hitung sebesar 6,090 dan tingkat signifikansi=0,000. Meskipun demikian, pendapatan keluarga tidak berpengaruh signifikan terhadap fertilitas (signifikansi 0,4758).

Dari kedua model estimasi, dapat diberikan estimasi jalur pada Gambar 2 berikut:

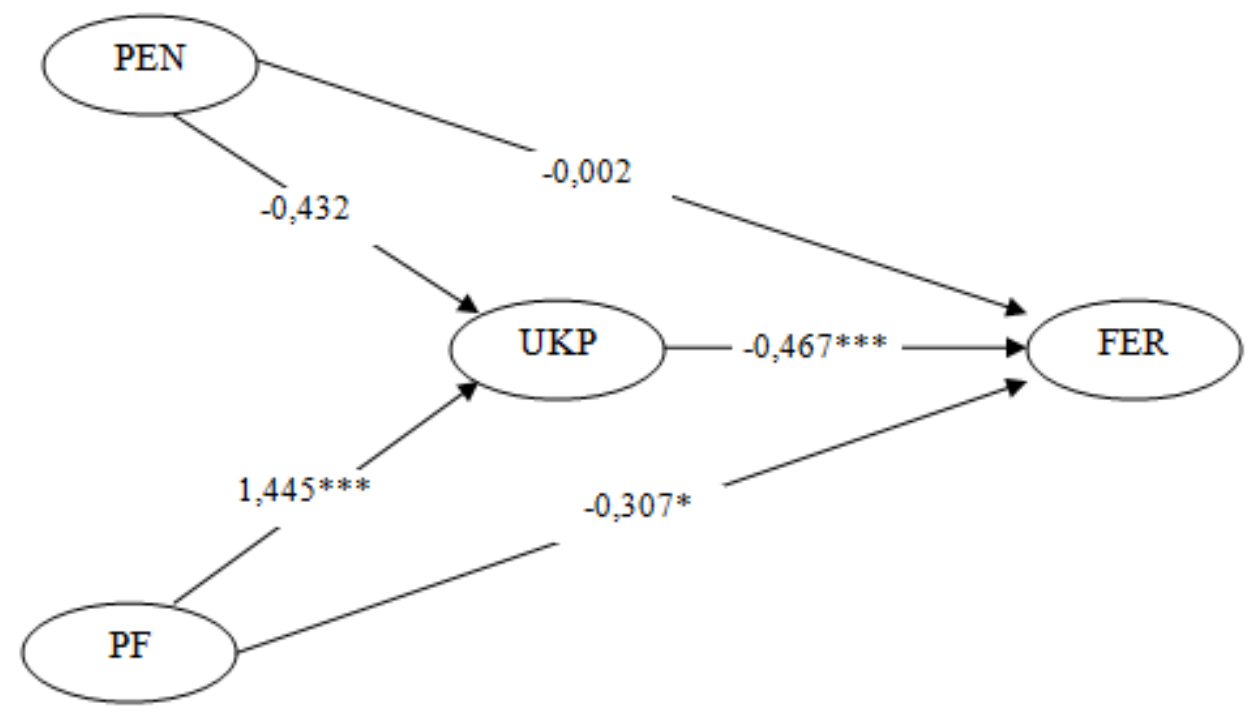

\section{Gambar 2. Estimasi jalur}


Berdasarkan Gambar 2 dapat dikemukakan hal-hal sebagai berikut:

1. Terdapat pengaruh langsung yang signifikan antara pendidikan formal terhadap usia kawin pertama dan fertilitas dengan besaran pengaruh (koefisien beta) masingmasingnya 1,445 dan $-0,307$.

2. Pendapatan tidak memiliki pengaruh langsung secara signifikan baik terhadap usia kawin pertama maupun fertilitas.

3. Terdapat pengaruh langsung yang signifikan antara usia kawin pertama terhadap fertilitas, dengan besaran pengaruh (koefisien beta) sebesar -0,467.

4. Karena tidak signifikannya pengaruh langsung pendapatan terhadap usia kawin pertama, juga tidak dapat diestimasi pengaruh tidak langsung pendapatan pada fertilitas melalui usia kawin pertama.

5. Terdapat pengaruh tidak langsung antara pendidikan terhadap fertilitas melalui usia kawin pertama. Besaran pengaruhnya adalah sebesar -0,67482 di dapat dari ($1,445 \mathrm{X}-0,467)$.

6. Pengaruh total pendidikan terhadap fertilitas adalah penjumlahan pengaruh langsung dengan pengaruh tidak langsungnya yaitu sebesar -0,98182.

\section{PENUTUP}

\section{Kesimpulan}

1. Secara simultan pendidikan wanita, pendapatan keluarga dan usia kawin pertama berpengaruh signifikan terhadap fertilitas.

2. Secara parsial berdasarkan analisis jalur dapat dikemukakan hal-hal sebagai berikut:

a. Usia kawin pertama berpengaruh signifikan negatif terhadap fertilitas. Semakin tinggi usia kawin pertama, akan menurunkan tingkat fertilitas

b. Pendidikan wanita berpengaruh signifikan negatif terhadap fertilitas baik secara langsung maupun tidak langsung melalui usia kawin pertama.

c. Pendapatan tidak berpengaruh signifikan terhadap fertilitas baik secara langsung maupun secara tidak langsung melalui usia kawin pertama.

\section{Saran}

a. Perlunya upaya pemerintah dalam meningkatkan pendapatan masyarakat melalui pembukaan lapangan kerja dan pendanaan usaha mikro kecil menengah yang dapat mendukung perekonomian masyarakat lebih di tingkatkan. Seiring dengan berjalannya waktu perbaikan pendapatan penduduk akan berdampak penurunan pertumbuhan penduduk atau fertilitas.

b. Mengintensifkan kembali wajib belajar 12 tahun, yang diikuti penurunan biaya pendidikan serta subsidi pendidikan bagi kaum kurang mampu. Dengan masa sekolah yang lebih panjang diharapkan akan menunda pernikahan terutama bagi remaja, dan di harapkan akan menurunkan tingkat fertilitas.

\section{DAFTAR PUSTAKA}

Adioetomo Sri Moertiningsih dan Samosir Omas Bulan. (2011). Dasar-Dasar Demografi Edisi Revisi 2. Jakarta: Selamba Empat

Eka, Dian. (2013). Faktor-faktor yang Mempengaruhi Fertilitas Pada Wanita Pekerja di Kota Makassar (rumah tangga miskin). $\underline{\text { Http://repository.unhas }}$ 
.ac.id/bitstream/handle/123456789/1200/SKRIPSI\%20DIAN\%20EKA\%20

L.docx? sequence $=1$.

Hardiani,H; Junaidi,J. (2011). Analisis kuantitas dan kualitas penduduk sebagai orientasi pembangunan di Provinsi Jambi. Laporan Penelitian. Kerjasama BKKBN dengan PSK UNJA. Jakarta

Hatmadji, Sri Harjati. (2004). Dasar-Dasar Demografi. Jakarta. LPFE-UI

Junaidi,J; Hardiani,H. (2009). Dasar-dasar teori ekonomi kependudukan. Jakarta. Hamada Prima

Mantra, Ida Bagus.). Demografi Umum . Jakarta : Pustaka Raja.

Rakhmatullah. A. (2015). Makalah Fertilitas. Https://ml.scribd.com/doc/246027969/ makalah-fertilitas 